[Agr. Biol. Chem., Vol. 28, No. 11, p. 779 787, 1964]

\title{
Pectic Enzymes in the Clarification of Apple Juice
}

\author{
Part I. Study on the Clarification Reaction in a \\ Simplified Model* \\ By Makari Yamasaki, Tsuneo Yasur**, and Kei Arima \\ Department of Agricultural Chemistry, Faculty of Agriculture, \\ University of Tokyo \\ Received June 1, 1964
}

\begin{abstract}
To know the role of pectic enzymes in the clarification reaction of apple juice, a simplified model for apple juice, that is, aqueous re-suspension of ultracentrifugal precipitates of apple juice, was employed. It was found that the precipitates (i.e., suspended materials) contained $36 \%$ of protein and that the surface of the suspended materials was negatively charged at pH 3.5. Positively charged colloids at $\mathrm{pH} 3.5$ such as gelatin enhanced the clarification reaction or mutually coagulated with the suspended materials. While negatively charged colloids at $\mathrm{pH} 3.5$, such as sodium alginate completely inhibited the clarification reaction. The direct participation of pectic enzymes in the clarification of apple juice was shown, and a supposed mechanism of the enzymic clarification was presented.
\end{abstract}

\section{INTRODUCTION}

It has long been known that pectic enzymes were responsible for the clarification of cloudy fruits juices.

And several investigators ${ }^{1-5)}$ studied the clarification phenomenon, though the mechanism of it has long been unelucidated.

Of course, it has not been known too that how many kinds of pectic enzymes or what kind of other enzymes are responsible for the clarification. Recently Endồ ${ }^{6)}$, however, discovered that only two kinds of pectic enzymes, i.e., purified endo-polygalacturonase I and pectinesterase, could cooperatively cause the clarifica-

* This report was presented at the 222 th meeting of Kanto Section of Agricultural Chemical Society of Japan, Tokvo, Dec. 1, 1962.

** Present address: Faculty of Agriculture, Tokyo University of Education, Komaba-cho, Meguro-ku, Tokyo.

1) Z.I. Kertesz, N.Y. Stale Agr. Expt,, Bull., 589, 3 (1930).

2) J.J. Willaman and Z.I. Kertesz, N.Y. Stale Agr. Expl. Sta. Tech. Bull., No. 178,3 (1931).

3) A. Mehlitz and M. Scheuer, Biochem. Z., 268, 345, 355 (1934).

4) M.A. Joslyn, S. Mist, and E. Lambert, Food Technol. 6, 133 (1952).

5) C.E. Neubeck, J. Assoc. Offe. Agr. Chemists, 42, 374 (1959).

6) A. Endo, Procceding of the annual mecting of the Agricultural Chemical Society of Japan, Tokyo, 1963, p. 4.; A. Endô, Proceeding of 15 th Symposium on Enzyme Chemistry, Osaka, 1963, p. 126. tion reaction.

To know the role of the pectic enzymes in the clarification reaction, it seems necessary for the authors to adopt more simplified system than apple juice which is very complicated system.

The authors happened to know that the suspended materials in apple juice could be precipitated by ultracentrifugation, e.g., $75,000 \mathrm{~g}$ for thirty minutes without using pectic enzymes, and that the ultracentrifugal precipitates were readily re-suspended in water or other aqueous solutions, resulting in stable suspensions.

These suspensions may be regarded as simplified models for apple juice. The present paper deals with several observations on the clarification phenomenon in the re-suspension systems, and the colloidal properties of the suspended materials in apple juice.

\section{MATERIALS AND METHODS}

\section{Apple Juice}

The variety of apple: Kôgyoku, pasteurized at $60^{\circ} \mathrm{C}$ for one hour, pH: 3.50 , sp. gr. $1.037\left(\right.$ at $25^{\circ} \mathrm{C}$ ), total acid: $0.434 \%$ (as malic acid), pectin: $0.13 \%$ (as anhydro- 
galacturonic acid). Before use, lees were filtered off with cotton.

\section{Chitosan Acetate}

Chitosan acetate was prepared from chitin after Tracey's method. ${ }^{\text {i) }}$

Infrared spectra revealed that the absorption bands around $1570 \mathrm{~cm}^{-1}$ and $1650 \mathrm{~cm}^{-1}$ characteristic of amide bond in the $\mathrm{N}$-acetyl group were almost disappeared.

\section{Alginase}

Crude alginase preparation was obtained from whole liver of abalone (Haliotis discus hannai) after Tsujino and Saitô's method. ${ }^{83}$

\section{Preparation of Enzymic Precipitates}

Apple juice was treated with a pectinase preparation (Miles Lab., Clifton, New Jersey, U.S.A.) at the concentration of $0.5 \mathrm{mg} / \mathrm{ml}$ of juice. Reacted three hrs. at $40^{\circ} \mathrm{C}$, precipitates were collected by centrifugation at 3,500 r.p.m. for $20 \mathrm{~min}$. The precipitates were re-suspended in a dilute $\mathrm{HCl}$ solution ( $\mathrm{pH} 3.50$ ) and centrifuged.

The washing was repeated three times. The final precipitates were re-suspended in the dilute $\mathrm{HCl}$ solution and lyophilized.

\section{Preparation of Ultracentrifugal Precipitates}

The apple juice was ultracentrifuged at $75,000 \mathrm{~g}$ for 30 minutes.

The precipitates were re-suspended in the dilute $\mathrm{HCl}$ solution and ultracentrifuged again. This washing was repeated once again.

The final precipitates were re-suspended in the dilute $\mathrm{HCl}$ solution and lyophilized.

\section{Bioassy of Amino Acids}

Both enzymic and ultracentrifugal precipitates were hydrolyzed and routinely bioassayed for 18 amino acids. Samples were hydrolyzed as follows: (1) for methionine and histidine, in 10 times volume of $5 \mathrm{~N} \mathrm{HCl}$ at $120^{\circ} \mathrm{C}$ for 2 hrs., (2) for tryptophan, in 10 times volum of $3.5 \mathrm{~N}$ $\mathrm{NaOH}$ with cysteine $(40 \%)$ at $120^{\circ} \mathrm{C}$ for $6 \mathrm{hrs}$, (3) for other amino acids, in 10 times volume of $6 \mathrm{~N} \mathrm{HCl}$ at $120^{\circ} \mathrm{C}$ for $6 \mathrm{hrs}$.

\section{Determination of Sugar Components}

The sugar components of both enzymic and ultracentrifugal precipitates were examined paper-chromatographically by using pyridine, ethyl acetate, water $(5: 12: 4)$ as the solvent and ammoniacal silver nitrate or anilinephthalate as the color reagents.

7) M.V. "Tracey, Biochem. J., 61, 579 (1955).

8) I. Tsujino and T. Saito, This journal, 26, 115 (1962).
Nearly $20 \mathrm{mg}$ of each precipitate was suspended in 4 $\mathrm{ml}$ of $1 \mathrm{~N} \mathrm{HCl}$ and heated at $100^{\circ} \mathrm{C}$ for eight hrs. in a sealed tube. After $\mathrm{HCl}$ was removed by the concentration repeated under reduced pressure, the hydrolyzate was dissolved in $0.5 \mathrm{ml}$ of distilled water and the solution resulted was spotted $10 \sim 15$ times on a Tôyô filter paper No. $51(40 \times 40 \mathrm{~cm})$ This paper was developed twice in the solvent aforementioned.

\section{Clarification Reaction}

Apple juice was ultracentrifuged at $75,000 \mathrm{~g}$ for 30 minutes.

Under this condition, almost all pectin in the juice remained in the supernatant. The precipitates were usually re-suspended in a final $0.05 \mathrm{M}$ acetate buffer $(\mathrm{pH}$ 3.50 ) with or without an aid of mortar. The re-suspensions were always at the same concentration as that found in original juice in relation to suspended materials.

These suspensions could be clarified by pectinase (Miles Lab.) faster than in the case of the original apple juice. The clarification reaction was always carried out at $\mathrm{pH}$ 3.50 and $40^{\circ} \mathrm{C}$, and the reaction mixture was $5 \mathrm{ml}$ in total. The time required for the first appearance of the flocculation of the suspended materials was recorded. Other detail of experimental conditions will be shown in individual experiments.

\section{Electrophoresis of the Suspended Materials}

The twice concentrated re-suspension in $0.01 \mathrm{M}$ acetate buffer ( $\mathrm{pH} 3.50$ ) was electrophoretically migrated in a small U-tube under the condition of $26.5 \mathrm{~mA} / \mathrm{cm}^{2}$ and $11 \mathrm{~V} / \mathrm{cm}$. The section area and the mean current path of the U-tube were $0.94 \mathrm{~cm}^{2}$ and $18 \mathrm{~cm}$ respectively. The electrode vessels and the U-tube, which was being dipped in ice bath during electrophoresis, were connected with agar-agar bridges.

Determination of the Amount of Galacturonide Liberated from the Suspended Materials by the Action of Pectinase.

The twice concentrated re-suspension in the dilute $\mathrm{HCl}$ solution ( $\mathrm{pH}$ 3.50) was treated by pectinase (Miles Lab.) at the concentration of $0.1 \mathrm{mg}$ per $\mathrm{ml}$ of the suspension at $40^{\circ} \mathrm{C}$. At a given time, $10 \mathrm{ml}$ of aliquot was withdrawn and immediately ultracentrifuged at $75,000 \mathrm{~g}$ for 7 min. Pectic substances in $9.5 \mathrm{ml}$ of supematant were demethylated with $0.5 \mathrm{ml}$ of $1 \mathrm{~N} \mathrm{NaOH}$ for $30 \mathrm{~min}$. at room temperature. Exactly $2 \mathrm{ml}$ of the reaction mixture was applied to the quantitative analysis of pectic substances by the colorimetric method with carbazole. ${ }^{9.1}$ 9) E.A. McComb and R.M. McCready, Anal. Chem., 24, 1630
(1952). 


\section{RESULTS}

\section{Com parison between Enzymic and Ultracentrifugal Precipitates}

The dry matter weight and the elementary compositions of the enzymic and ultracentrifugal precipitates are shown in Table I.

The compositions of amino acid of both precipitates are compared in Table II. As for the sugar components, both precipitates were found to contain at least four kinds of sugar, i.e., arabinose, galactose, glucose, and galacturonic acid. (Fig. 1)

From these data, any notable difference between both precipitates could not be observed.

Liberation of Galacturonides from the Suspended Materials by the Action of Pectic Enzymes

As the suspended materials in apple juice contained galacturonic acid as their component as shown in Fig. 1, pectin or hemicellulose contain-

Table I. The Comparison of Dry Matter

Weight, Elementary Composition and Ash

BETWEEN THE ENZYMIC AND ULTRACENTRIFUGAL Precipitates.

$\begin{array}{lcc} & \text { Enzymic } & \text { Ultracentrifugal } \\ \text { Dry matter* } & 0.051 \% & 0.046 \% \\ \text { Nitrogen } & 6.02 \% & 5.80 \% \\ \text { Carbon } & 55.13 \% & 54.35 \% \\ \text { Hydrogen } & 7.11 \% & 6.58 \% \\ \text { Ash } & \fallingdotseq 2 \% & <2 \%\end{array}$

* Expressed in weight percentage in original apple juice.

ing galacturonic acid residue may be the components or protective colloids of the suspended materials. Then it is expected that galacturonic acid or galacturonides will be liberated from the suspended materials by the action of pectic enzymes.

As expected, galacturonic acid or galacturonides were liberated by pectic enzymes as shown

Table II. The Comparison of Amino Acid Compostrions

$\begin{array}{lcc}\text { Asp. } & 3.70 \% & 3.48 \% \\ \text { Glu. } & 4.59 & 4.31 \\ \text { Gly. } & 2.37 & 2.14 \\ \text { Ala. } & 2.72 & 2.67 \\ \text { Val. } & 2.47 & 2.18 \\ \text { Leu. } & 3.01 & 2.69 \\ \text { lleu. } & 2.06 & 1.81 \\ \text { Pro. } & 1.81 & 1.70 \\ \text { Phe. } & 1.86 & 1.72 \\ \text { Tyr. } & 1.31 & 1.13 \\ \text { Try. } & 0.47 & 0.28 \\ \text { Ser. } & 2.18 & 1.91 \\ \text { Thr. } & 1.93 & 1.69 \\ \text { Met. } & 0.68 & 0.50 \\ \text { Cys. } & 0.43 & 0.27 \\ \text { Arg. } & 2.34 & 1.97 \\ \text { His. } & 0.81 & 0.68 \\ \text { Lys. } & 2.54 & 2.38 \\ \text { Total } & 37.28 & 33.31 \\ \text { No\% } \times 6.25 & 37.6 & 36.3\end{array}$

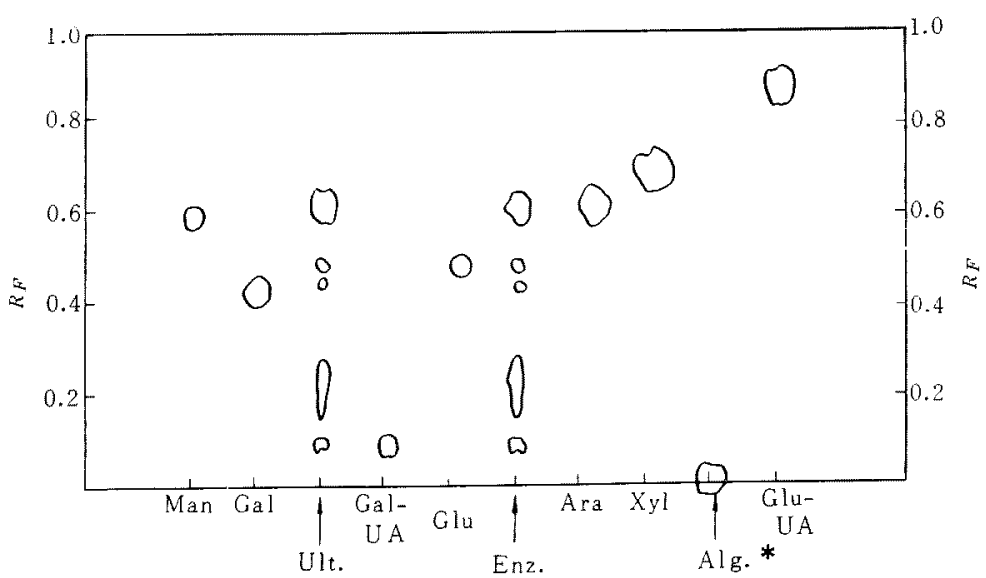

FIG. 1. Paper Chromatogram of the Hydrolyzates of Enzymic and Ultracentrifugal Precipitates. Alg.*: Enzymic bydrolyzate of alginic acid as a standard for mannuronic acid. 


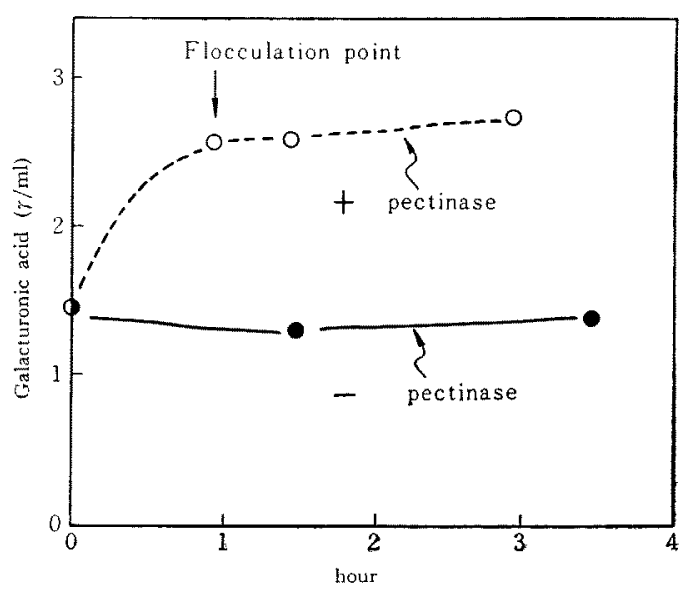

FIG. 2. The Liberation of Galacturonides by the Action of Pectinase.

in Fig. 2. For purposes of qualitative analysis, the reaction mixture in the colorimetric analysis was diluted with distilled water. Pink color turned to colorless in a few minutes. This means that there was no detectable amount of concomitants of hexoses. ${ }^{102}$ As the suspended materials contained galacturonic acid as the sole uronic acid component, the liberated substances were determined as galacturonic acid or galacturonides.

The liberated amount was as much as endogeneous amount of galacturonides in the supernatant.

Effect of the Concentration of Pectin on the Clarifcation Reaction.

The viscosity of apple juice is mainly ascribed to pectin in the juice. The effect of the con-

Table III. The Effect of the Concentration of Pectin on the Clarification Reaction

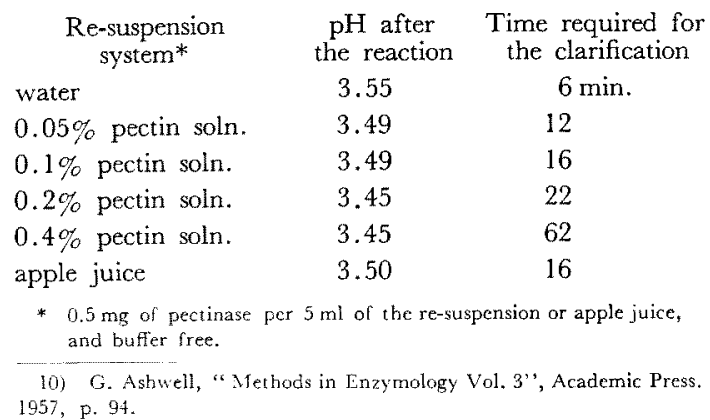

centration of pection on the clarification reaction was studied by applying re-suspension systems.

From the data shown in Table III, following facts could be pointed out: (l) The water resuspension was clarified much faster than original apple juice. (2) The clarification reaction was apparently retarded with the increase of the amount of pectin in the resuspensions.

\section{Effect of $\mathrm{pH}$ on the Clarification.}

It was incidentally found that the enzymic clarification reaction did not occur at $\mathrm{pH} 6.0$ at least within several hours. But the clarification reaction occurred after some lag time (about three minutes), if the apparently unchanged reaction mixture was adjusted to $\mathrm{pH} 3.5$ with an appropriate buffer. On the other hand, the clarification reaction under the similar condition was observed after six minutes, if the reaction was carried out at $\mathrm{pH} 3.5$ from the beginning. This means that enzymic reactions proceeded even at $\mathrm{pH} 6.0$ without resulting in the clarification and that the clarification reaction was dependent on $\mathrm{pH}$ of the re-suspensions.

Then the effect of $\mathrm{pH}$ on the clarification reaction was studied.

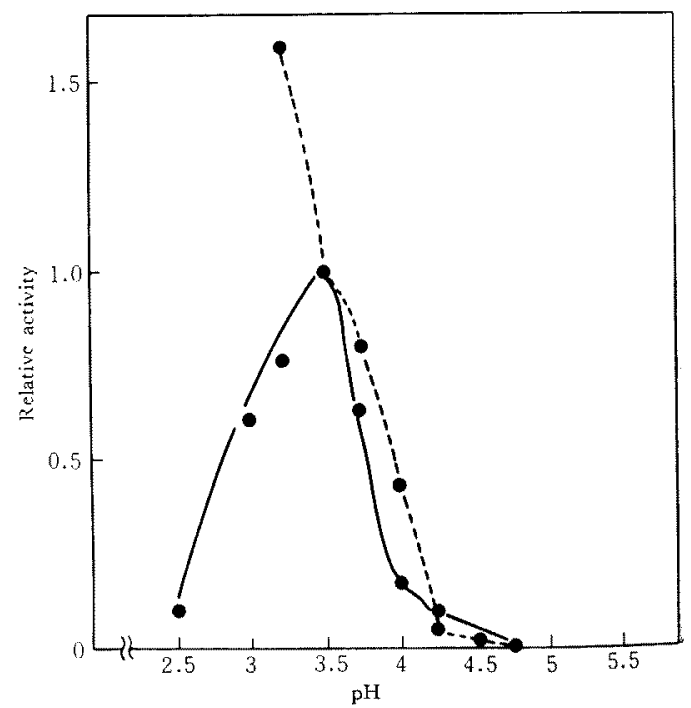

Fig. 3. The Effect of $\mathrm{pH}$ on the Clarification Reaction.

The clarifying activity at $\mathrm{pH} 3.5$ was referred to as 1.0 .

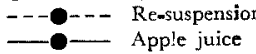


As shown in Fig. 3, the reaction could never be observed above $\mathrm{pH} 4.75$ either with apple juice or the re-suspensions. A great difference, however, of the behavior to $\mathrm{pH}$ was observed below $\mathrm{pH} 3.5$ between apple juice and the resuspensions. The enzymic clarifying activity was retarded with the decrease of $\mathrm{pH}$ value in apple juice, while the flocculation of the suspended materials in the re-suspension was markedly accelerated along with increase of acidity. Below $\mathrm{pH} 3.0$ in the re-suspension systems, it will be more accurate to say that the mutual coagulation between the suspended materials and enzyme proteins occurred in place of enzymic clarification reaction.

\section{Interaction between the Suspended Materials and Molecular Colloids.}

The amount of pectin markedly affected the time required for the clarification. (Table III) Then the effect of the presence of various kinds of molecular colloids on the clarification reaction was studied. The suspended materials seemed to be negatively charged, because the non-

Table IV. The Effect of the Presence of Various Kinds of Colloids on the Clarification Reaction

\begin{tabular}{|c|c|c|c|c|}
\hline $\begin{array}{l}\text { Sorts of } \\
\text { colloid }\end{array}$ & $\begin{array}{l}\text { Concn. } \\
\text { tested }\end{array}$ & $\begin{array}{c}\text { Clarifica- } \\
\text { tion } \\
\text { reaction* }\end{array}$ & $\begin{array}{l}\text { Mutual } \\
\text { coagn. } * *\end{array}$ & $\begin{array}{c}\text { Charge at } \\
\mathrm{pH} 3.5\end{array}$ \\
\hline Pectin & $0.05 \sim 0.2 \%$ & + & - & - \\
\hline Na-pectate & $" \prime$ & + & - & - \\
\hline Na-alginate & $\prime \prime$ & - & - & - \\
\hline $\mathrm{CMC}$ & 11 & - & - & - \\
\hline Gum arabic & 11 & - & - & - \\
\hline $\begin{array}{l}\text { Soluble } \\
\text { starch }\end{array}$ & $0.17 \sim 0.67 \%$ & to + & - & 0 \\
\hline Inulin & $0.05 \sim 0.2$ & + & - & 0 \\
\hline Dextran & $\prime \prime$ & + & - & 0 \\
\hline $\begin{array}{l}\text { Chitosan } \\
\text { acetate }\end{array}$ & $0.025 \%$ & & + & + \\
\hline Albumin & $0.05 \%$ & & + & + \\
\hline Gelatin & $\prime \prime$ & & + & + \\
\hline Casein & 11 & & + & + \\
\hline Pepsin*** & $0.2 \%$ & + & - & - \\
\hline $\begin{aligned} * & \text { Re-susp } \\
* * & \text { Mutual } \\
* * * & \text { Pepsin } \\
& \text { poratios }\end{aligned}$ & $\begin{array}{l}\text { ension systems con } \\
\text { coagn: Non-enz } \\
\text { (Crys.): Purchased } \\
\text {, Ohio, U.S.A. }\end{array}$ & $\begin{array}{l}\text { ntained } 0.75 \\
\text { zymic mutua } \\
\text { ed from Nutr }\end{array}$ & $\begin{array}{l}\mathrm{mg} \text { of pectina } \\
\text { sal coagulation } \\
\text { ritional Bioch }\end{array}$ & $\begin{array}{l}\text { se per } 5 \mathrm{ml} \text {. } \\
\text { emicals Cor- }\end{array}$ \\
\hline
\end{tabular}

enzymic mutual coagulation occurred when positively charged colloids were added. (Table IV) In apple juice system, however, this mutual ? coagulation could not be observed in spite of adding a large amount of positive colloids.

Negatively charged colloids such as sodium alginate, GMC, and gum arabic completely inhibited the clarification reaction even at the final concentration as low as $0.05 \%$.

Electrostatically neutral colloids, such as dextran or inulin, had little effect on the clarification, but the reaction time was a little prolonged by the addition of soluble starch.

\section{Surface Electrostatic Charge of the Suspended Ma-} terials.

To know more exactly the electrostatic charge of the surface of the suspended materials, the electrophoresis was applied. At first Tiselius type apparatus was used with samples of apple juice or the re-suspensions dialyzed against an appropriate buffer as stated by Oki. ${ }^{11}$ But this method did never give good results.

Then the classical method using a U-tube as reported by Endô ${ }^{6}$ ' was employed with a slight modification. All the suspended materials migrated to anode within 60 minutes. This result is consistent with the observations reported by Ôki ${ }^{11}$ and Endô. ${ }^{63}$

\section{Effect of a Small Amount of Protein.}

It has long been known that the stability of a hydrophobic colloid having either positive or negative charge is reduced by adding a smoll amount of a hydrophilic colloid having opposite

\section{Table V. The Effect of the Presence of a Small Amount of Proteins}

Treatment

pectinase $^{17}$

pectinase $^{1)}+$ protease $^{\mathrm{g} / *}$

pectinase $^{13}+$ heated protease $^{2 \text { ? }}$

pectinase $^{1}$ theated pectinase ${ }^{2}$

pectinase $^{1)}+$ casein $^{2)}$

1) $0.06 \mathrm{mg}$ of pectinase per $5 \mathrm{ml}$ of the resuspension.

2) $0.12 \mathrm{mg}$ of protein per $5 \mathrm{ml}$ ol the re-suspension.

* protcase: Partially purified protease of Streptomyces griseus kindly given by Dr. M. Nomoto.

11) T. Óki, J. Agr. Chem. Soc., Japan, 33, 1005 (1959). 
charge. This phenomenon called "sensitization" was also found in the re-suspension systems. (Table V) It is clear that the time required for the clarification was markedly shortened by the addition of a small amount of proteins. But the sensitization phenomenon could not be observed in the case of apple juice.

As far as examined, proteases had no accelerating effect on the clarification reaction.

\section{Effect of Negatively Charged Colloids.}

The fact that sodium alginate or carboxymethyl cellulose (CMC) completely inhibited the clarification reaction can be understood by the alternative explanation either that the added pectinase and these colloids reacted to form complex coacervates resulting in the loss of the enzymic activity, or that these colloids acted as protective colloids for the suspended materials. The formation of complex coacervates, however, could never be detected even microscopically. Then sodium alginate or $\mathrm{CMC}$ which pectic enzymes can not attack seems to act as protective colloids.

If so, inhibitory effect of sodium alginate or CMC will be deservedly lost by premtreating with alginase or cellulase respectively.

The data shown in Table VI were obtained under the condition that $100 \mathrm{ml}$ of $0.4 \% \mathrm{CMC}$

Table VI. The Effects of the Presence of Negatively Charged Colloms and the Pretreatment of the Colloidos on the ClakificaTION REACTION

$\begin{array}{lccc}\begin{array}{c}\text { Re-suspension } \\ \text { system* }\end{array} & \begin{array}{c}\text { Final } \\ \text { conc. of } \\ \text { colloid }\end{array} & \text { Pretreatment } & \begin{array}{c}\text { Time re- } \\ \text { quired for } \\ \text { the } \\ \text { clarification }\end{array} \\ \text { Na-pectate soln. } & 0.05 \% & \text { +(pectinase) } & 6.5 \mathrm{~min} . \\ \text { Na-pectate soln. } & 0.10 & + \text { (pectinase) } & 6.5 \\ \text { Na-pectate soln. } & 0.05 & - & 11.5 \\ \text { CMC soln. } & 0.05 & + \text { (cellulase) } & 37 \\ \text { CMC soln. } & 0.10 & + \text { (cellulase) } & 210 \\ \text { CMC soln. } & 0.05 & - & - \\ \text { Na-alginate soln. } & 0.05 & + \text { (alginase) } & 20 \\ \text { Na-alginate soln. } & 0.10 & + \text { (alginase) } & 27.5 \\ \text { Na-alginate soln. } & 0.05 & - & - \\ \text { * Reaction mixture contained : } 0.5 \mathrm{ml} \text { of } 0.5 \mathrm{~m} \text { acetate buffer pH } \\ \text { 3.5, 2.0 ml of the twice concentrated rc-suspension of the sus- } \\ \text { pended materials, 2.0 ml of pre-treated or non-treated colloid } \\ \text { solution, and } 0.5 \mathrm{ml} \text { of pectinase soln. }(0.5 \mathrm{mg} / \mathrm{ml}) \text {. }\end{array}$

solution ( $\mathrm{pH}$ 5.0) was pretreated with $15 \mathrm{mg}$ cellulase (of Trichoderma coningi, Ueda Kagaku Co.) at $37^{\circ} \mathrm{G}$ for $19 \mathrm{hrs}$, and that $100 \mathrm{ml}$ of $0.4 \%$ sodium alginate solution $(\mathrm{pH} 6.0)$ was pretreated with $10 \mathrm{ml}$ of crude alginase solution at $37^{\circ} \mathrm{C}$ for $19 \mathrm{hrs}$.

As is shown in Table VI, pre-treated negatively charged colloids had no more inhibitory effect on the clarification.

If pectic enzymes and cellulase were added simultaneously to the system containing $\mathrm{CMC}$, the clarification reaction was expected to occur as well. The clarification reaction was observed only when both pectinase (Miles Lab.) and cellulase (Ueda Kagaku Co.) existed as shown in Table VII. As the pectinase used in this experiment contained rather high CMCase activity, it partly caused the clarification, only if the reaction period was prolonged to $24 \mathrm{hrs}$.

\section{Table VII. The Role of Pectic Enzymes in} the Clarification

\begin{tabular}{|c|c|c|}
\hline $\begin{array}{l}\text { Re-suspension } \\
\text { system }\end{array}$ & $\begin{array}{l}\text { Enzymes } \\
\text { added* }\end{array}$ & $\begin{array}{l}\text { Time required for } \\
\text { he clarification }\end{array}$ \\
\hline Buffer & pectinase & $10 \mathrm{~min}$. \\
\hline Buffer & cellulase & 一 \\
\hline CMC $0.05 \%$ soln. & pectinase & - \\
\hline CMC $0.05 \%$ soln. & cellulase & - \\
\hline CMC $0.05 \%$ soln. & $\begin{array}{l}\text { pectinase }+ \\
\text { heated cellulase }\end{array}$ & - \\
\hline CMC $0.05 \%$ soln. & pectinase + cellulase & $5.5 \mathrm{hrs}$ \\
\hline $\begin{array}{l}\text { pectinase: } 0.5 \mathrm{n} \\
\text { cellulase: } 1.0 \mathrm{n}\end{array}$ & $\begin{array}{l}\text { r } 5 \mathrm{ml} \text { of the re-sus } \\
\text { r } 5 \mathrm{ml} \text { of the re-susp }\end{array}$ & Sion. \\
\hline
\end{tabular}

\section{DISCUSSION}

The suspended materials were supposed to contain about $36 \%$ of protein on the basis of good accordance between calculated protein content (nitrogen content $\times 6.25$ ) and total amino acid content, and the presence of 18 natural amino acids. (Table II)

This protein would be positively charged at $\mathrm{pH} 3.50$, provided that the isoelectric point of the protein was between $\mathrm{pH} 4.0$ and 5.0. And this protein was supposed to exist as a proteincarbohydrate complex from the following facts: (1) The enzymic precipitates, which were thought to be partly or wholly deprived of their 
protective colloid, pectin, by the action of pectic enzymes, could not be solubilized by partially purified pronase which had the wide substrate specificity. ${ }^{12) *}$ (2) Both enzymic and ultracentri- fugal precipitates contained at least three kinds of sugar in addition to galacturonic acid.

On the other hand, judging from the interaction with various kinds of molecular colloids

(A) Below $\mathrm{pH} 4.0$

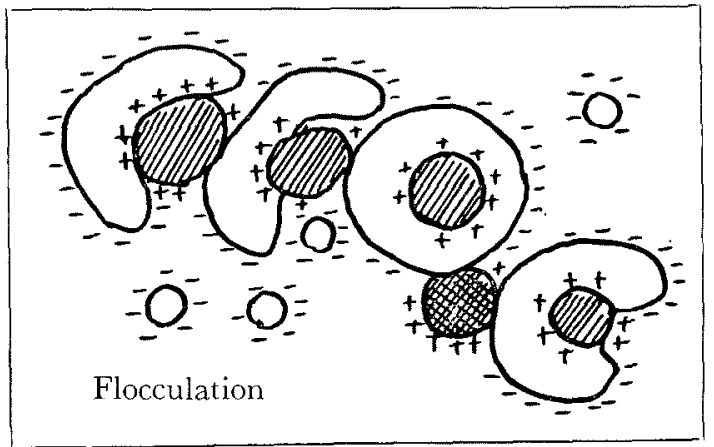

(B) Above $\mathrm{pH} 5.0$

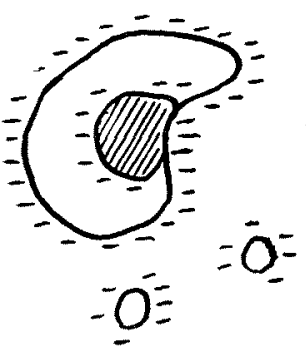

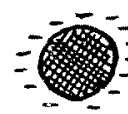

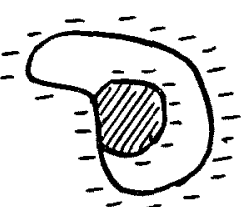

$=0-0-$
(C) Blocking effect

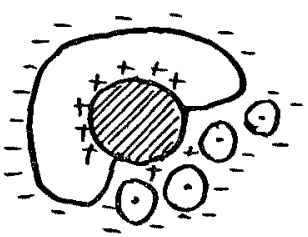

Fig. 4. A Supposed Mechanism of the Flocculation.

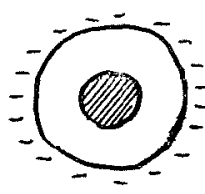

Suspended materials.

The protein-carbohydrate complex is surrounded by negatively

charged protective colloids, such as pectin.)

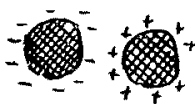

Enzymes or proteins.

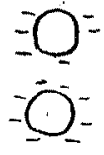

Prectin

Negatively charged protective colloids which pectic enzymes can not attack.

* pronase: protease of Streptomyces griseus kindly given by Dr. M.

Nomoto.

12) M. Nomoto, Y. Narahashi. and M. Murakami, J. Biochem.,

48, 593, $906(1960)$ 
and the result of the electrophoresis, the surface of the suspended materials was negatively charged.

Assumed that the protein-carbohydrate complex was surrounded by the negatively charged protective colloids, e.g., pectin, positive charge of the complex would be exposed by the whole or partial degradation of the protective colloid with pectic enzymes. Then appeared positive charge of the complex and the neighbouring negative charge of the protective colloid which was not yet degraded by the action of pectic enzymes would attract to each other, resulting in the flocculation. (Fig. 4A) If the $\mathrm{pH}$ of the re-suspension system was above 4.75 , the charge of the complex would be converted to negative so that the flocculation could not be occurred. (Fig. 4B)

The sensitization by a small amount of proteins (supposed to be positively charged at $\mathrm{pH}$ 3.5) can be understood as the connecting effect of the proteins among negatively charged protective colloids. When the concentration of proteins was elevated, the mutural coagulation occurred in place of the sensitization. In apple juice system, the sensitization and the mutual coagulation could not be observed. This may be partly because of the pre-existence of soluble proteins in apple juice. Freshly prepared apple juice, however, showed mutual coagulation between large particles of the suspended materials and added gelatin (at the final concentration of $0.0005 \sim 0.05 \%$ ). It was well-known that the addition of gelatin improved the enzymic clarification reaction of apple juice. ${ }^{13)}$ This effect of gelatin is explained as an agent causing mutual coagulation and/or sensitization.

The fact that negatively charged colloids which pectic enzymes could not attack, such as sodium alginate and carboxymethyl cellulose, completely inhibited the clarification reaction even at the low concentration was explained as the blocking effect in which exposed positive charge of the complex was blocked or neutralized by the added negative colloids. (Fig. 4C) In

13) E. Schubert, Schweizer Brautei-Rundschau, Nr. 3 und 4, 1 (1951). apple juice system, pectin may act as the protective colloid for the suspended materials. For the complete clarification of cloudy apple juice, pectin should be degraded by the action of pectic enzymes and be lost its protective or blocking effect.

\section{SUMMARY}

(1) Gloudy apple juice could be clarified by ultracentrifugation, e.g., 75,000 g for 30 minutes, without using pectic enzymes. The ultracentrifugal precipitates were readily able to be resuspended in water or in other aqueous solutions, resulting in stable suspensions. These suspensions were regarded as simplified models for apple juice.

(2) Any notable difference was not found between the enzymic and ultracentrifugal precipitates in relation to dry matter weight, elementary composition, ash, amino acid and sugar compositions. Both precipitates were found to. contain about $36 \%$ of protein.

(3) The enzymic clarification reaction was. observed below $\mathrm{pH} 4.75$, but not above $\mathrm{pH} 4.75$ in the cases of apple juice and the re-suspensions.

(4) Judging from the interactions with other colloids and the results of electrophoresis, the surface of the suspended materials in apple juice. was thought to be negatively charged.

(5) The enzymic clarification reaction in the re-suspension systems was markedly accelerated by the addition of a small amount of protein.

(6) Negatively charged molecular colloids, such as sodium alginate or carboxymethyl cellulose even at the low concentration, completely inhibited the clarification reaction.

(7) From the electrostatical and colloidal points of view, a supposed mechanism of the flocculation of the suspended materials was presented.

Acknowledgements. The authors wish to thank Dr. G. Tamura for many helpful discussions. and suggestions during this work. The authors also wish to thank Professor S. Koga of the Institute of Applied Microbiology and Dr. K. Horikoshi of the Institute of Scientific Research 
for helpful advices, and Professor B. Maruo of the Institute of Applied Microbiology for kind teaching in operating Tiselius type electrophoresis apparatus. The authors also thank $\mathrm{Mr}$.
M. Kobayashi of Meijiya Co., Ltd. for supplying a large amount of apple juice and Mr. S. Eguchi of Ajinomoto Co., Ltd. for bioassay of amino acids. 